\title{
高エネルギーX線テレビ用螢光板
}

\author{
名古屋市立東市民病院 \\ 沢田武司 \\ 東芝電気株式会社砂町工場 \\ 山本敏 雄 \\ 東芝電気株式会社玉川工場 \\ 松井実
}

\section{THE PROPERTIES OF SEVERAL KINDS OF SCREENS FOR HIGH ENERGY X-RAY TV}

\author{
by Takeshi Sawada \\ Nagoya East City Hospital \\ by Toshio Yamamoto
}

Tokyo Shibaura Electric Co. Ltd., Sunamachi work by Minoru Matui

Tokyo Shibaura Electric Co. Ltd., Tamagawa Work

\section{Summary}

We discussed the characteristics of the screens in order to develop the TV apparatus for high energy X-ray. This X-ray TV apparatus was used to check the irradiated field during irradiation. Our device was equipped with a screen anb an ultra-sensitivity TV camera (Silicon-electron multiplication). We investigated the following problems of several kinds of screens, because we considered the property of the screen played an important role in case of high energy X-ray. These were the relation between the brightness of screens and the dose of high energy $\mathrm{X}$-ray or the thickness of $\mathrm{Pb}$-foil. Here we reported our results of measurements on characteristics of screens in this paper.

\section{1. 緒言}

ライナック治療中照射野確認のために，超高感度テレ ビカメラと蛍光板との組合せ方式によるX線テレビ装置 を開発する目的で高エネルギー用蛍光板の検討を行なっ た。使用する蛍光体は放射線用として一般に使用されて いる $\mathrm{ZnCdS}: \mathrm{Ag}, \mathrm{ZnS}: \mathrm{Ag}, \mathrm{BaSO}_{4}: \mathrm{Pb}, \mathrm{CaWO}_{4}$ 等で, その蛍波長及び残光特性を变化させた場合のテレビ画像 に及ばす影響や，鉿べースの厚みと照射エネルギーの変 化による画像への影篦を調へた。これらの結果加ら高工 ネルギー用蛍光板を試作し，実験仙っってその実用性が 珰められたので報告する。
尚，本実騃には最近開発された超高感度形S E Mテン ビカメラ (Silicon electron multiplication)を使用した。

\section{2. 実験材料及び方法}

1）放射線源：LMR-13型ライナック（東芝製）

$$
\text { エネルギー， } 8,10,12 \mathrm{MeV}
$$

2) ファントム:Mix-Dp, ラントファントーム

3）蛍光板 : ZnCdS : Ag, $\mathrm{ZnS}: \mathrm{Ag}, \mathrm{BaSO}_{4}: \mathrm{Pb}$ $\mathrm{CaWO}_{4}$.

4）鉛スクリーン: 0.5 22 $\mathrm{mm}$

5) その他使用機器 : PI- 2 型極微照度計 GV-201C型VTR 


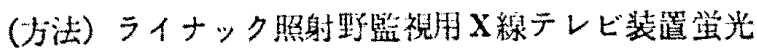
板開発のための営光板の輝度測定及じテレビモニターに よる画像について検討した、ライナックX線照射による 蛍光板の輝度は極めて低照射度の測定よなるので，反射 鏡を使わずに直接測定を行う予定であったが，一次線錐 の影響により指示計のバックグランドが十分除去できな かったので一次線錐から離しテレビカメラ上同位置で行 なった。照度測定時は営光板の発生面皘を $90 \times 90 \mathrm{~mm}^{2}$ に较って暗箱内の反射を少くなるようにした。（図一 (1))。測定条件は鉛スクリーン，Mix-Dpの厚み，X線 エネルギー， $\mathrm{X}$ 線々量の变化と各種蛍光板の輝度を比較 した. また，䖝光透視像のテレビカメラによるモニター 画啠との対芯を検討した。

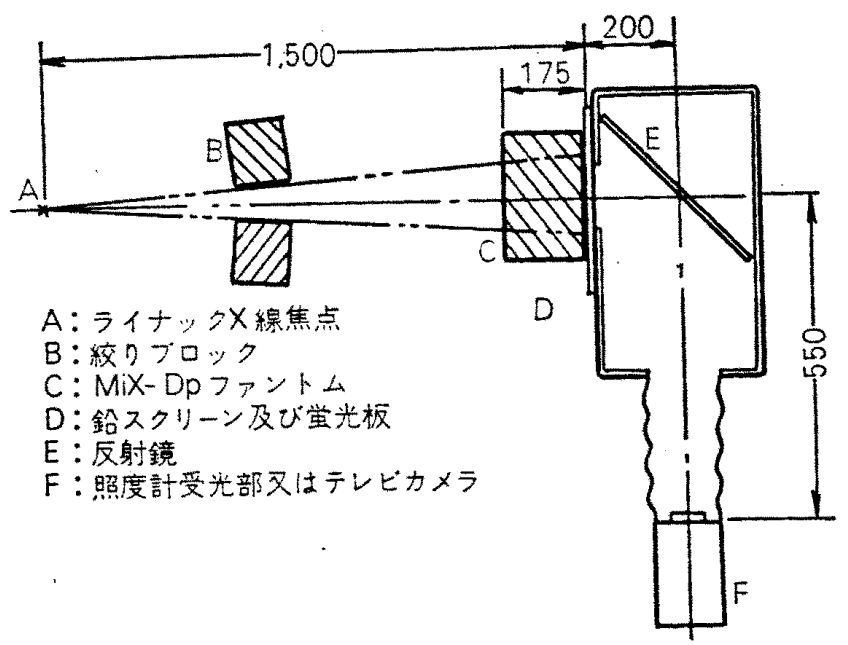

図 1 実験 配 置

\section{3. 実験結果}

(1) 鉛スクリーンの摩さについて

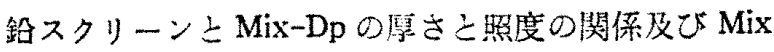
一D をファントームにしたときの鉛スクリーンと照度の 関係は夫々図一（2）の如くである．蛍光体 $\mathrm{ZnS}: \mathrm{Ag}$ で $10 \mathrm{MeV} \mathrm{X}$ 線 $200 \mathrm{R} / \mathrm{min}$ におりる测定最大照度は，1， $15 \times 10^{-3}(1 \mathrm{x})$ であっだ。この朋るさは本実験の SEM テ レビカメラで十分余﨏のある明るさであり，治療使用線 量範团内 $(300 \mathrm{R} / \mathrm{min} \sim 200 \mathrm{R} / \mathrm{min})$ に収まり奏用出来た。 鉛スクリーンの厚みは1〜3 $\mathrm{mm}$ 間に輝度のピークがあ りビルドアップを羿めた。実際にビルドアップ補正用上 しての羟スクリーンの厚さは，10MeV X線で $1.5 \mathrm{~mm}$ 程

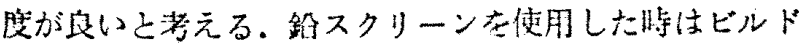
アップ效果は認められなかった。

最終的に虽光板を選ふに対して，䖢光体の種類により

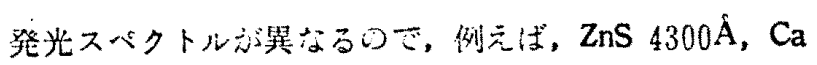
wo $_{4} 4120 \AA$, ZnCdS : Ag $5300 \AA$ 等各種の発光ピークを 持つため、テンビカメラ部撮像管の分比特性 (S20光電

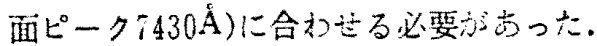

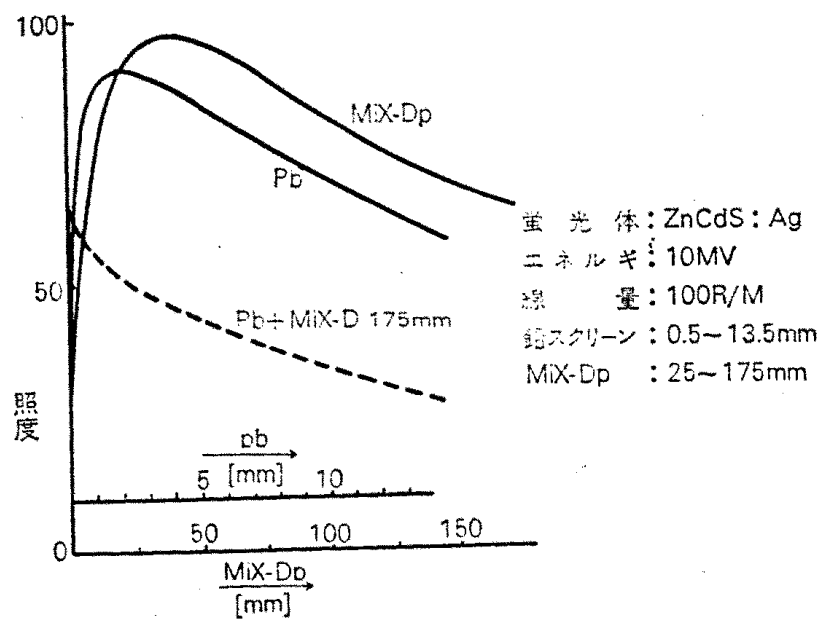

図 2

(2) 営光体の種類とX線エネルギーにつけて 蛍光物質の遠いによる鉛スクリーンと照照度の関係は 図一(3)の如くである。明るさの順位は $\mathrm{ZnS}: \mathrm{Ag} ， \mathrm{ZnCdS}$ $: \mathrm{Ag}, \mathrm{CaWO}_{4}$ である。何れす煇度的には不足はない ガ，画質は極めてフラットでエネルギ一依存性は殆んじ 浔められず，三種類の蛍光体の差簧もない、ただ，残光

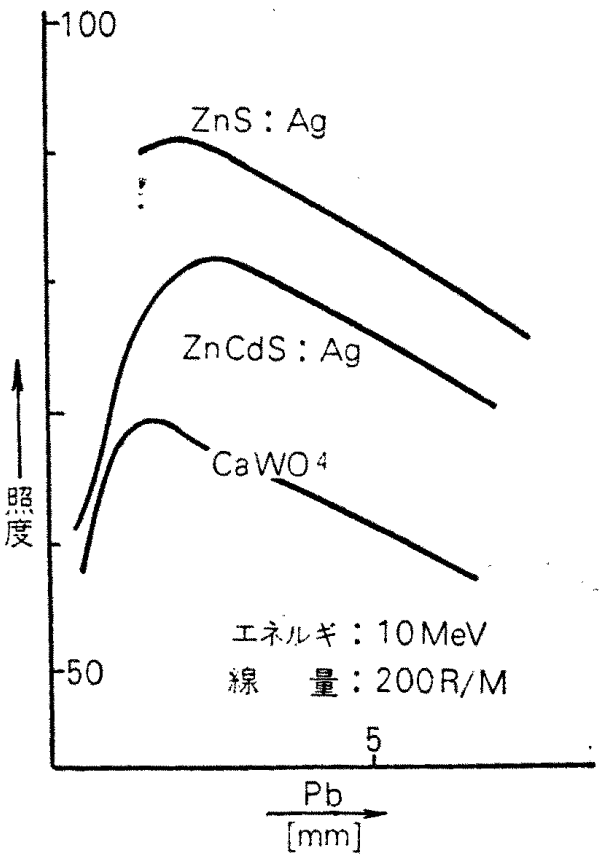

図 3 
性蛍光体を使用した名のは残像が長く、コントラストが 低下ぎみであるので，回転照射中の T.V 画像を考える と不適当であった。照度目盛は相対比較值とした。但， 照度的な特性を $\mathrm{ZnS}: \mathrm{Ag}$ と $\mathrm{ZnCdS}: \mathrm{Ag}$ がほぼ等しい とみるとフフォントムが無い時は明るさのエネルギー 依存性が大きく，有る時は殆んど依存性がなくなる。 (表一(1)).

表 1 照度とエネルギ一传存性

\begin{tabular}{|c|c|c|c|}
\hline \multirow{2}{*}{$\begin{array}{c}\text { I } n \neq- \\
{[\mathrm{MeV}]}\end{array}$} & 照 & \multicolumn{2}{|c|}{ 度 (相対值) } \\
\hline & $\begin{array}{c}\mathrm{Mix}-\mathrm{Dp} \\
25 \mathrm{~mm}\end{array}$ & $\begin{array}{r}\text { Mix-Dp } \\
100 \mathrm{~mm} \\
\end{array}$ & $\begin{array}{l}\text { Mix-Dp } \\
175 \mathrm{~mm}\end{array}$ \\
\hline 8 & 21 & 16 & 11.8 \\
\hline 10 & 21.5 & 17 & 12.5 \\
\hline 12 & 22 & 17.5 & 13 \\
\hline
\end{tabular}

鉛スクリーン: $1.5 \mathrm{~mm}$

線 量: $100 \mathrm{R} / \mathrm{M}$

（3）蛍光体の種類とコントラスト

蛍光体の材罂によるコントラスト優劣順位は，モ二タ 一画像とVTR画像比較した結果, $\mathrm{ZnCdS}: \mathrm{Ag}, \mathrm{ZnS}$ : $\mathrm{Ag}, \mathrm{CaWO}_{4}$ で照度の測定データとほぼ一致した。但し 鉛スクリーンは1.0mmを使用した。（図一-(4)），また。 鉛スクリーンの厚さがコントラストに与える影響は 0.5 $\sim 6 \mathrm{~mm}$ 程度変化しても肉眼では, はっきりした差が認 めら放い，蛍光体に昤スクリーン $10 \mathrm{~mm}$ を加えて人

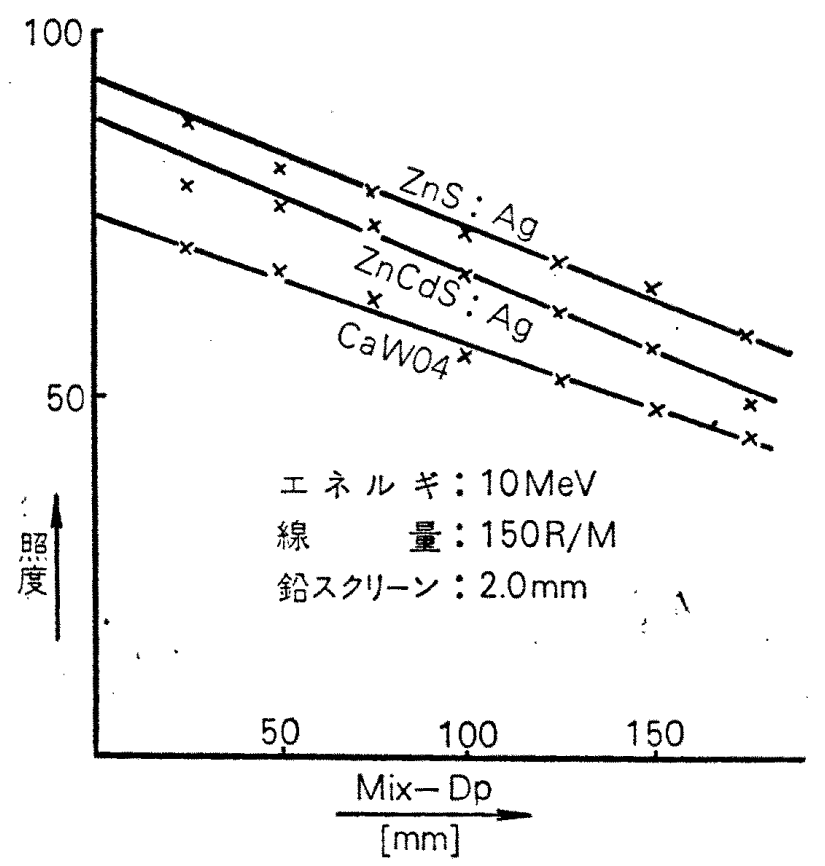

図 4
体ファントームをテレビ装置で鹳察したときの画質優劣 順位は，ZnS: Ag, ZnCdS: Ag, $\mathrm{CaWO}_{\text {\& }}$ であった。日 常私どるが放射線治療に採用しているエネルギ一は10 MV X線であるが，乙れを $8 \mathrm{MV} ， 6 \mathrm{MV}$ と低い領域を 用いるとコントラストが上昇した。しかし，超高任領域 では本来被写体コントラストが低いので，TV画像にお いてあコントラストは増強されないが、幾らかで良い との考えから，蛍光体の発光スベクトルを修正方るた的 に色フイルターをカメラ部の前面に取りつけて撮像した が効果はなかった。 また，X線照射中に含まれる電子線 の效果がコントラストに悪影響を及ぼすのではないかと

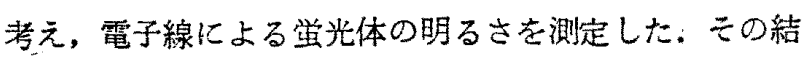
果，電子線による明るさはX線に比へて約 $1 / 40$ に低下 し，直接にT V 画像には影響していないと考える。

(4) 解像力について解像力テストチャートして鉄材試 験として，鉄材を吸収体として厚み $200 \mathrm{~mm}$ では $6 \mathrm{~mm} \phi$ 丸棒の検出が限界であった，又，被写体を用いた場合で はアクリライト段階に $10 \mathrm{~mm} \phi$ 及び $5 \mathrm{mn} \phi$ の孔が十分

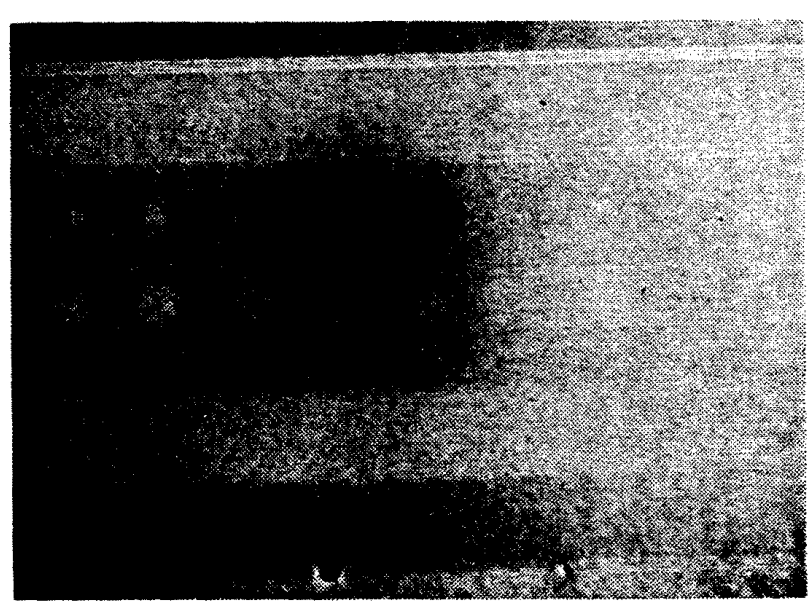

写真1 $10 \mathrm{~mm} 5 \mathrm{~mm}$

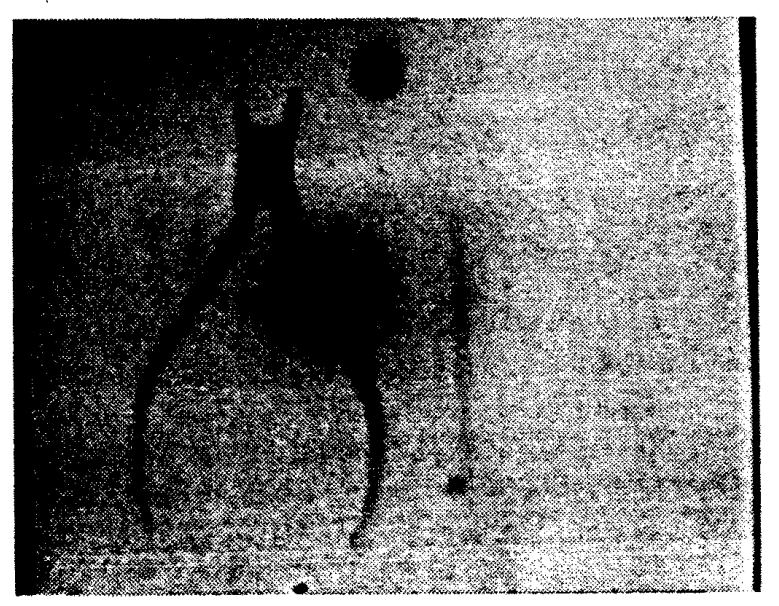

写真 2 ドライバーロニッパー 
検出可能であった。（写真一(1)）

又，被写体しして頭部ランドフォントームを使用した 所, 側面像の概観像が良く認める事が出来たが，蛍光板 の違いによる画質の変化は影著に認められなかった。

(5) $\mathrm{T}$ v画像につけて

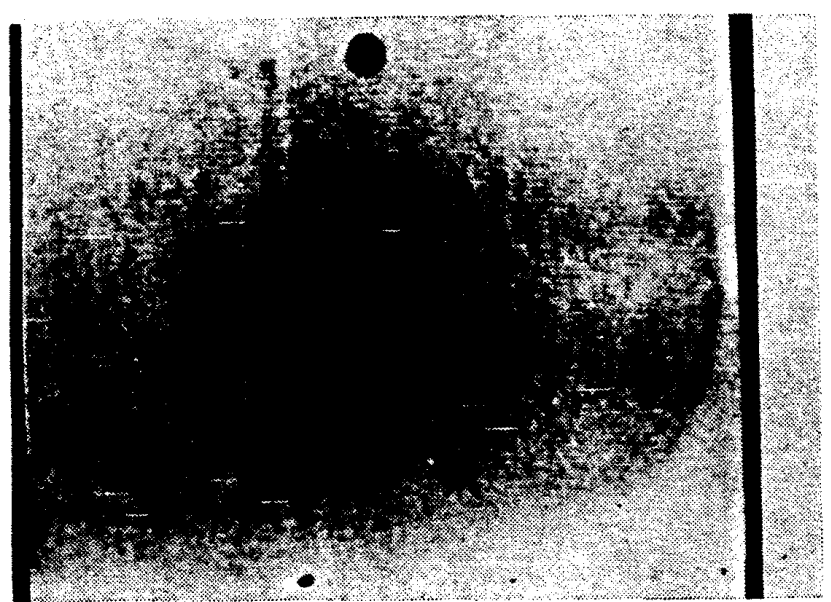

写真 3 頭部フェントーム正面像

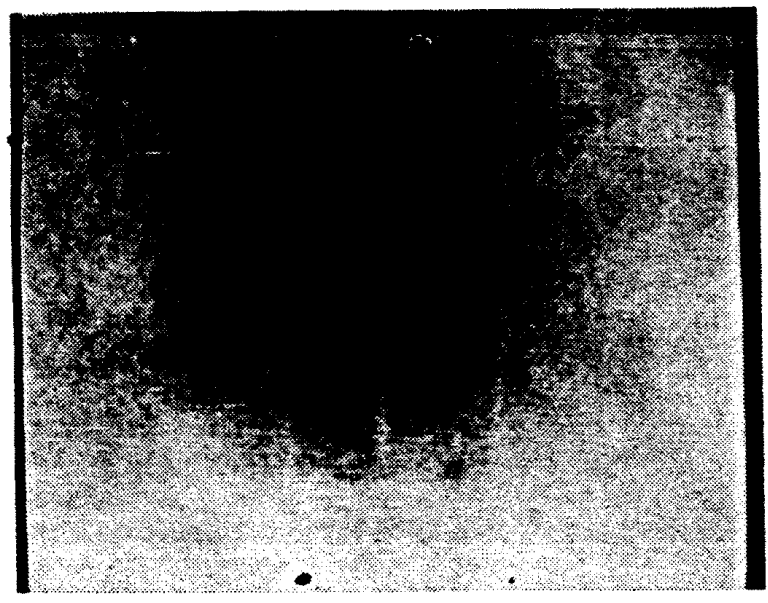

写窴 4 頭部フォントーム側面像

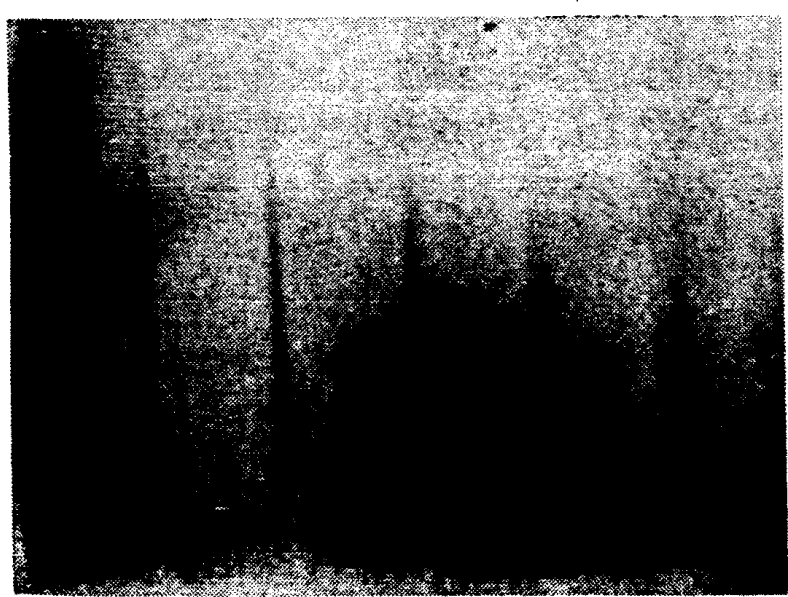

写真 5 胸部ファントーム左側
今四私ざすが試作した照射野碓認用のX線テレビ画像 示す. (真写 2 ～5 ) この条件は 10MV X線 200R/min 照射中の監視用テレビ画像を $35 \mathrm{~mm}$ フィルムで撮影し たものである。

\section{4. 考察}

（1）全般に吸収体コントラストカj低い原因としては， 物質の吸收係数に対して透過エネルギ一が大きいなか 止むをえない上若えられる.少しですコントラストを高 めるために萤光膜の光吸収, 及びテレビカメラへの色フ イルター装着を行ってす顕著な効果が得られなかった。

(2) 残光性学光体は実用上特化運動照射の上き残像广今 問題となった。

（3）鉛スクリーン，Mix-Dp 等の吸収体を用いた時の 蛍光板発光輝度は，線量測定と同様なビルドアップ特性 が羿められた。

(4) 図一（2）加らあ分るように鉛スクリーンは出来る だけ薄いはうが有利である。

(5) 解像力としてT V 受光面でペネトラ 4 本 $/ \mathrm{cm}$ 娭出 可能で,アクリライトによるテストでは $5 \mathrm{~cm} \dot{\phi}$ の孔が十 分確認できた。

\section{5. 結語}

高エネルギーX線テレビ営光板用 蛍光体としては， $\mathrm{ZnCdS}: \mathrm{Ag}, \mathrm{ZnS}: \mathrm{Ag}, \mathrm{CaWO}_{4}$ 等が使える。また，あ る程度の鉛スクリーンを付加したすのが画質的に向上す る.

今後臨床面でのデーターを参照の上検討を進めたい。

\section{6.あとがき}

虽光板の諸特性を確認する㬰験の開始に当っては, 文 献等について, 愛知県がんセンタ一放射線部北川部長に いろいろお世話になったことを感謝いたします。

\section{文献}

MALVEN R., ROSENGREN B., WALLMAN H. FIELD CONTROL IN ROENTGEN THERAPY WITH A $5 \mathrm{MeV}$ LINEAR ACCELERATOR BY MEANS OF TELEVISION. Acta Radiol. Ther. Phys. Biol. 7(1968), 462.

BENNERS., ROSENGREN B., WALLMAN $H$. and NETTELANDO. TELEVISION MONITORING OF 30MV X.RAY BEAM. Phys. in Med. Biol. i(1962), 29. 